\title{
FAKTOR-FAKTOR PENENTU PERTUMBUHAN EKONOMI DI KOTA/KABUPATEN SE SULAWESI UTARA
}

\author{
Debby Ch. Rotinsulu ${ }^{1}$, Antonius Y. Luntungan ${ }^{2}$, Jecline I Sumual ${ }^{3}$ \\ ${ }^{123}$ Jurusan Ekonomi Pembangunan, Fakultas Ekonomi dan Bisnis, \\ Universitas Sam Ratulangi, Manado 95115, Indonesia \\ Email : debby_rotin@yahoo.com
}

\begin{abstract}
ABSTRAK
Pembangunan Ekonomi adalah merupakan salah satu upaya dalam rangka mendukung pelaksanaan salah satu prioritas yang tercantum dalam Prioritas Pembangunan Nasional, yaitu mempercepat pemulihan ekonomi dan memperkuat landasan pembangunan ekonomi berkelanjutan dan berkeadilan berdasarkan sistem kerakyatan. Penetapan prioritas tersebut mendasarkan pada masalah dan tantangan yang dihadapi serta arah kebijakan dalam pembangunan ekonomi, baik pembangunan jangka pendek maupun jangka menengah (Propenas 2002-2004). Tujuan utama dari pembangunan ekonomi itu sendiri adalah untuk meningkatkan kesejahteraan masyarakat secara Nasional maupun daerah, yang dinilai berdasarkan laju pertumbuhan ekonominya.

Pertumbuhan ekonomi yang ditargetkan untuk dicapai tak bisa hanya berjalan sendiri, namun ada beberapa faktor penting yang perlu untuk menjadi perhatian dan bahan pertimbangan dalam menunjang target pencapian pertumbuhan ekonomi. Dalam penelitian ini, peneliti ingin mengetahui faktor-faktor manakah yang mempengaruhi pertumbuhan itu sendiri dan seberapa besar pengaruh masingmasing faktor tersebut. Objek penelitian ini di kota/kabupaten di Sulawesi Utara. Dari hasil estimasi regresi berganda ternyata pertumbuhan ekonomi di Kota Bitung di pengaruhi oleh variabel belanja pemerintah dan luas lahan. Artinya, dengan adanya pertambahan belanja pemerintah akan memberikan pengaruh yang positif terhadap pertumbuhan ekonomi di Kota Bitung. Belanja pemerintah Kota Bitung sudah mampu mendorong pertumbuhan yang ada di kota tersebut begitu juga dengan luas lahan sudah mampu memberikan kontribusi yang positif bagi pertumbuhan ekonomi Kota Bitung. Akan tetapi variabel investasi di Kota Bitung memberikan pengaruh yang negatif terhadap pertumbuhan ekonomi dan belum mampu mendorong pertumbuhan ekonomi secara signifikan.

Variabel investasi memberikan pengaruh yang positif bagi pertumbuhan ekonomi di Kota Kotamobagu. Ternyata Investasi yang ada di Kota Kotamobagu mampu mendorong dan memberikan kontribusi bagi pertumbuhan ekonomi di kota tersebut. Tetapi belanja pemerintah dan luas lahan di Kota Kotamobagu memberikan pengaruh yang negatif terhadap pertumbuhan ekonomi di daerah tesebut dan tidak memberikan dorongan pertumbuhan ekonomi yang signifikan. Kepulauan Sangihe untuk variabel belanja pemerintah, investasi dan luas lahan memberikan pengaruh positif terhadap pertumbuhan ekonomi di daerah tersebut akan tetapi belum mampu mendorong dan memberikan kontribusi yang signifikan. Variabel belanja pemerintah, investasi dan luas lahan memberikan pengaruh negatif terhadap pertumbuhan ekonomi di Kota Manado. Ternyata belanja pemerintah di Kota Manado tidak memberikan kontribusi bagi pertumbuhan ekonomi begitu juga dengan investasi yang dilakukan dan luas lahan yang bertambah di Kota Manado tidak memberikan dorongan pertumbuhan ekonomi secara signifikan.
\end{abstract}

Kata Kunci : Belanja Pemerintah, Investasi, Luas Lahan dan Pertumbuhan Ekonomi 


\section{PENDAHULUAN}

\section{Latar Belakang}

Pertumbuhan ekonomi merupakan sebuah proses berkelanjutan dari waktu ke waktu dan mengindikasikan perbaikan di dalam perekonomian, yang juga sering diartikan sebagai penambahan kemampuan produksi yang diwujudkan dalam kenaikan pendapatan nasional. Hakekat pembangunan nasional menurut Propenas adalah rencana pembangunan yang berskala nasional serta nasional serta mertipakan konsekuensi dan kornitmen bersama masyrakat Indonesia mengenai pencapaian visi dan misi bangsa. Dengan demikian, fungsi Propenas adalah untuk menyatukan pandangan dan derap langkah seluruh lapisan masyrakat dalam melaksanakan prioritas pembangunan selamna lima tahun ke depan. (Propenas 2000-2004). Tujuan utama dari pembangunan ekonomi itu sendiri adalah untuk meningkatkan kesejahteraan masyarakat secara Nasional maupun daerah, yang dinilai berdasarkan laju pertumbuhan ekonominya.

Pertumbuhan ekonomi yang ditargetkan untuk dicapai tak bisa hanya berjalan sendiri, namun ada beberapa faktor penting yang perlu untuk menjadi perhatian dan bahan pertimbangan dalam menunjang target pencapian pertumbuhan ekonomi. Selain alokasi belanja pemerintah pertumbuhan ekonomi di daerah juga perlu ditunjang dengan investasi, dimana investasi ini akan membuat perputaran roda perekonomian semakin cepat, dikarenakan adanya sumber pendanaan lain yang masuk ke daerah dengan demikian maka akan mengembangkan sektorsektor perekonomian yang dimiliki atau bahkan membuka sektor perekonomian baru yang belum terjamah sebelumnnya. Hal tersebut tentu akan membuka lebih luas lagi kesempatan kerja di daerah. Tenaga kerja juga merupakan salah satu faktor penting dalam perekonomian yang berkembang, dikarenakan setiap sektor ekonomi yang sedang berkembang juga membutuhkan faktor produksi dalam bentuk tenaga kerja yang semakin banyak, untuk itu kesiapan tenaga kerja yang dimiliki oleh daerah juga perlu untuk ditingkatkan, baik secara kuantitas maupun kompetensi yang dimiliki. Apabila tenaga-tenaga kerja yang sebelumnya tidak memiliki lapangan pekerjaan sudah bekerja maka perputaran perekonomian dan peningkatan pendapatan secara keseluruhan di daerah dapat dicapai dengan lebih baik lagi.

Selain faktor-faktor di atas yang tak kalah menarik untuk dilihat adalah bagaimana kemampuan lahan yang dimiliki oleh daerah, baik besaran luas yang dimiliki maupun sumber daya yang ada. Hal ini tentu perlu menjadi perhatian khusus baik pemerintah sebagai pemegang tampuk kebijakan maupun masyarakat secara keseluruhan. Dengan adanya luas lahan yang memadai dan sumber daya yang tersedia maka dapat dilihat bagaimana potensi real yang dimiliki oleh daerah dalam rangka mengembangkan perekonomian yang dimiliki. Sulawesi Utara sendiri sebagai salah satu daerah yang memiliki luas lahan yang cukup besar dan sumber daya baik alam maupun manusia mempunyai beberapa daerah baru yang ikut merasakan dampak dari pemberian kewenangan dalam bentuk otonomi daerah. Untuk itu menarik melihat bagaimana kinerja daerah-daerah di Sulawesi Utara dalam rangka meningkatkan perekonomian yang dimiliki oleh daerah masing-masing.

\section{Rumusan Masalah}

Berdasarkan latar belakang yang dipaparkan di atas maka rumusan masalah yang akan bisa diambil adalah :

- Bagaimana faktor-faktor penentu pertumbuhan ekonomi mempengaruhi pertumbuhan ekonomi di Kota/Kabupaten di Sulawesi Utara 


\section{Tujuan Penelitian}

Berdasarkan latar belakang dan perumusan masalah yang telah diambil maka tujuan penelitian ini adalah :

- Melihat bagaimana faktor-faktor penentu pertumbuhan ekonomi mempengaruhi pertumbuhan ekonomi di kabupaten/kota Sulawesi Utara

\section{Manfaat Penelitian}

1. Bagi pemerintah daerah penelitian ini diharapkan dapat memberikan informasi pentingnya mengoptimalkan potensi lokal yang dimiliki yang nantinya akan berdampak pada kesejahteraan masyarakat.

2. Sebagai bahan referensi dan informasi bagi masyarakat dan peneliti yang ingin melakukan penelitian selanjutnya.

3. Untuk menambah dan memperkaya wawasan ilmiah penulis dalam disiplin ilmu yang penulis tekuni.

\section{Tinjauan Pustaka}

\section{Pertumbuhan Ekonomi (Regional)}

Pertumbuhan ekonomi menunjukkan sejauh mana aktivitas perekonomian akan menghasilkan tambahan pendapatan masyarakat pada suatu periode tertentu. Perekonomian dianggap mengalami pertumbuhan bila seluruh balas jasa riil terhadap penggunaan faktor produksi pada tahun tertentu lebih besar daripada pendapatan riil masyarakat pada tahun sebelumnya. Kuznets (Jhingan, 2007) mengatakan bahwa pertumbuhan ekonomi adalah kenaikkan kapasitas dalam jangka panjang dari suatu negara untuk menyediakan barang-barang ekonomi bagi penduduknya.

Indikator yang digunakan untuk mengukur pertumbuhan ekonomi adalah tingkat pertumbuhan Produk Domestik Bruto (PDB) riil. Beberapa Konsep mengenai Pertumbuhan Ekonomi, menggambarkan bahwa dalam kegiatan perekonomian yang sebenarnya pertumbuhan ekonomi berarti perkembangan produksi barang dan jasa yang terjadi di suatu negara, seperti pertambahan dan jumlah produksi barang industri, perkembangan infrastruktur, pertambahan jumlah sekolah, pertambahan produksi sektor jasa dan pertambahan produksi barang modal.

Adam Smith dalam bukunya yang berjudul An Inguiry into the Nature and Causes of the Wealth of Nations (1776), menganalisis sebab berlakunya pertumbuhan ekonomi dan faktor yang menentukan pertumbuhan ekonomi. Inti dari ajaran Smith adalah agar masyarakat diberikan kebebasan yang seluas-luasnya dalam menentukan kegiatan ekonomi, dalam hal apa yang dirasakan baik untuk dilakukan.

Faktor-faktor yang mempengaruhi pertumbuhan ekonomi, dimaksudkan untuk menjelaskan faktor-faktor yang menentukan kenaikan output per kapita dalam jangka panjang, dan penjelasan mengenai bagaimana faktor-faktor tersebut berinteraksi satu sama lain sehingga terjadi proses pertumbuhan adalah berbeda sesuai dengan aliran atau pandangan yang dianut oleh para ahli-ahli ekonomi tersebut. 


\section{Belanja Pemerintah.}

Belanja pemerintah merupakan seperangkat produk yang dihasilkan dan memuat pilihan atau keputusan yang dibuat oleh pemerintah untuk menyediakan barang-barang publik dan pelayanan kepada masyarakat. Total pengeluaran pemerintah merupakan penjumlahan keseluruhan dari keputusan anggaran pada masing-masing tingkatan pemerintahan (pusat propinsi - daerah). Wade $(1990,174)$ menyatakan bahwa "the share of government expenditure in GDP is a good measure of the share of total resources subject to state control".

Oleh karena itu dalam memahami berbagai pengaturan pendanaan bagi pemerintah pusat (daerah) maka harus mengetahui keragaman fungsi yang dibebankannya. Fungsi-fungsi tersebut adalah: fungsi penyediaan pelayanan yang berorientasi pada lingkungan dan kemasyarakatan; fungsi pengaturan, yakni merumuskan dan menegakkan pusat perundangan; fungsi pembangunan, keterlibatan langsung maupun tidak langsung dalam bentuk-bentuk kegiatan ekonomi dan penyediaan prasarana; fungsi perwakilan, yaitu menyatakan pendapat daerah di luar bidang tanggungjawab eksekutif; fungsi koordinasi, yakni melaksanakan koordinasi dan perencanaan investasi dan tata guna tanah regional (daerah).

Menurut Arndt (1990) argumentasi mengenai kebijakan publik dalam kaitan dengan kebijakan pengeluaran pemerintah didasarkan pada situasi bahwa pasar tidak bisa berperan sendiri mengaktifkan mobilisasi aktivitas ekonomi terutama untuk mencapai efisiensi. Pengeluaran pemerintah (goverment expenditure) adalah bagian dari kebijakan fiskal (Sadono Sukirno, 2000) yakni suatu tindakan pemerintah untuk mengatur jalannya perekonomian dengan cara menentukan besarnya penerimaan dan pengeluaran pemerintah tiap tahunnya yang tercermin dalam dokumen APBN untuk nasional dan APBD untuk daerah/regional. Tujuan dari kebijakan fiskal ini adalah dalam rangka menstabilkan harga, tingkat output maupun kesempatan kerja dan memacu pertumbuhan ekonomi.

\section{Investasi dan Aset Produktif.}

Teori ekonomi mengartikan atau mendefinisikan investasi sebagai "pengeluaranpengeluaran untuk membeli barang-barang modal dan peralatan-peralatan produksi dengan tujuan untuk mengganti dan terutama menambah barang-barang modal dalam perekonomian yang akan digunakan untuk memproduksikan barang dan jasa di masa depan".

Menurut Boediono (1992) investasi adalah pengeluaran oleh sektor produsen (swasta) untuk pembelian barang dan jasa untuk menambah stok yang digunakan atau untuk perluasan pabrik. Dornbusch \& Fischer berpendapat bahwa investasi adalah permintaan barang dan jasa untuk menciptakan atau menambah kapasitas produksi atau pendapatan di masa mendatang.

Persyaratan umum pembangunan ekonomi suatu negara menurut Todaro $(2006,118)$ adalah: Akumulasi modal, termasuk akumulasi baru dalam bentuk tanah, peralatan fisik dan sumber daya manusia; Perkembangan penduduk yang dibarengi dengan pertumbuhan tenaga kerja dan keahliannya; dan kemajuan teknologi.

Akumulasi modal akan berhasil apabila beberapa bagian atau proporsi pendapatan yang ada ditabung dan diinvestasikan untuk memperbesar produk (output) dan pendapatan di kemudian hari. Untuk membangun seharusnya sumber-sumber daya yang dimiliki dialihkan dari yang semula tujuannya untuk konsumsi kemudian sumber-sumber daya tersebut dimanfaatkan untuk investasi dalam bentuk "capital formation" guna mencapai tingkat produksi 
yang lebih besar. Investasi di bidang pengembangan sumberdaya manusia akan meningkatkan kemampuan sumber daya manusia tersebut, sehingga menjadi tenaga ahli yang terampil yang dapat memperlancar kegiatan produktif.

Menurut Sadono Sukirno (2000) kegiatan investasi memungkinkan suatu masyarakat terus menerus meningkatkan kegiatan ekonomi dan kesempatan kerja, meningkatkan pendapatan nasional dan meningkatkan taraf kemakmuran masyarakat. Peranan ini bersumber dari tiga fungsi penting dari kegiatan investasi, yakni (1) investasi merupakan salah satu komponen dari pengeluaran agregat, sehingga kenaikan investasi akan meningkatkan permintaan agregat, pendapatan nasional serta kesempatan kerja; (2) pertambahan barang modal sebagai akibat investasi akan menambah kapasitas produksi; (3) investasi selalu diikuti oleh perkembangan teknologi.

\section{METODE PENELITIAN}

\section{Data dan Sumber Data}

Jenis data yang digunakan dalam penelitian ini adalah data sekunder, yang berupa data PDRB, pertumbuhan ekonomi, belanja pemerintah, investasi, dan lahan produktif. Karena keterbatasan waktu dan dana, maka dari 15 kabupaten/kota di Sulawesi Utara, 5 kabupaten/kota diambil menjadi objek penelitian ini. Keenam kabupaten/kota tersebut adalah: Kota Manado, Kota Kotamobagu, Kota Bitung, Kabupaten Minahasa Selatan dan Kabupaten Sangihe. Data tersebut diperoleh dari kantor Statistik dan Bagian keuangan masing-masing Kabupaten/Kota.

\section{Definisi Operasional dan Pengukuran Variabel}

Dalam penelitian ini variabel-variabelyang akan digunakan adalah:

1. Belanja Pemerintah Daerah adalah Pembelanjaan yang dilakukan oleh Pemerintah dikabupaten/Kota yang menjadi objek penelitian di Sulawesi Utara yang terdiri atas Belanja langsung dan tidak langsung yang di ukur dalam Satuan Rupiah/Tahun.

2. Investasi adalah jenis investasi yang dilakukan baik oleh pemerintah dan pihak swasta.

3. Lahan Produktif adalah jumlah luas lahan produktif yang dimiliki oleh masing-masing daerah, yang diukur dengan jumlah luas (hektar).

4. Pertumbuhan Ekonomi adalah perkembangan PDRB di masing-masing Kabupaten/kota, yang diukur dengan persentase per tahun

\section{Metode Analisis Data} berikut :

Metode analisis yang digunakan dalam penelitian ini meliputi langkah-langkah sebagai

1. Mengukur besarnya faktor-faktor yang mempengaruhi tertumbuhan ekonomi di masing-masing daerah penelitian

2. Membandingkan hasil yang diperoleh diantara kabupaten/kota, agar supaya mendapatkan faktor manakah yang paling perpengaruh di masing-masing kabupaten/kota.

Untuk menganalisis factor-faktor yang mempengaruhi pertumbuhan ekonomi di kabupaten/kota di Sulawesi Utara, akan digunakan analisis regresi berganda, yang dimulai dengan menetukan persamaan fungsional sebagai berikut: 
$\mathrm{Y}=\mathbf{f}(\mathrm{X} 1, \mathrm{X} 2, \mathrm{X3})$

Dimana : $\quad$ Y adalah Pertumbuhan Ekonomi

$\mathrm{X} 1$ adalah Belanja Pemerintah

$\mathrm{X} 2$ adalah Investasi

X3 adalah Luas Lahan Produktif

Data diolah dengan bantuan software SPSS seri 21.00. Pengujian hipotesis dilakukan dengan menggunakan model analisis regresi berganda untuk melihat pengaruh variabel independen terhadap variabel dependen (sekaran, 1992).

Beberapa langkah yang dilakukan dalam analisis regresi linier masing- masing akan dijelaskan di bawah ini:

\section{Uji Asumsi Klasik}

Pengujian regresi linier berganda dapat dilakukan setelah model dari penelitian ini memenuhi syarat-syarat yaitu lolos dari asumsi klasik. Syarat-syarat yang harus dipenuhi adalah data tersebut harus terdistribusikan secara normal, tidak mengandung multikoloniaritas, dan heterokedastisitas.

\section{Model Regresi Berganda}

Ada dua persamaan regresi, persamaan regresi adalah:

\section{Uji Hipotesis}

Ketepatan fungsi regresi sampel dalam menaksir nilai aktual dapat diukur dari Goodness of Fitnya. Secara statistik, setidaknya ini dapat diukur dari nilai koefisien determinasi, nilai statistik $\mathrm{F}$ dan nilai statistik t. Perhitungan statistik disebut signifikan secara statistik apabila nilai uji statistiknya berada dalam daerah kritis (daerah dimana Ho ditolak). Sebaliknya disebut tidak signifikan bila nilai uji statistiknya berada dalam daerah dimana Ho diterima (Ghozali, 2006).

\section{Koefisien Determinasi}

Koefisien determinasi $\left(\mathrm{R}^{2}\right)$ pada intinya mengukur seberapa jauh kemampuan model dalam menerangkan variasi variabel independen. Koefisien determinasi ini digunakan karena dapat menjelaskan kebaikan dari model regresi dalam memprediksi variabel dependen. Semakin tinggi nilai koefisien determinasi maka akan semakin baik pula kemampuan variabel independen dalam menjelaskan variabel dependen (Ghozali, 2006). Nilai koefisien determinasi adalah antara nol dan satu. Nilai $\mathrm{R}^{2}$ yang kecil berarti kemampuan variabel-variabel independen dalam menjelaskan variasi variabel dependen amat terbatas. Nilai yang mendekati satu berarti variabel- variabel independen memberikan hampir semua informasi yang dibutuhkan untuk memprediksi variasi variabel dependen. Dimana

\section{Uji Signifikansi Simultan (Uji Statistik F)}

Uji Statistik F pada dasarnya menunjukkan apakah semua variabel independen atau bebas yang dimasukkan dalam model mempunyai pengaruh secara bersama-sama terhadap variabel dependen (Ghozali, 2006). Cara untuk mengetahuinya yaitu dengan membandingkan nilai $\mathrm{F}$ hitung dengan nilai $\mathrm{F}$ tabel. Apabila nilai $\mathrm{F}$ hitung lebih besar daripada nilai $\mathrm{F}$ tabel, 
maka hipotesis alternatif diterima artinya semua variabel independen secara bersama-sama dan signifikan mempengaruhi variabel dependen.

\section{Uji Signifikansi Parameter Individual (Uji Statistik t)}

Uji statistik t pada dasarnya menunjukkan seberapa jauh pengaruh satu variabel independen secara individual dalam menerangkan variasi variabel dependen (Ghozali, 2006). Uji statistik $t$ ini digunakan karena untuk memperoleh keyakinan tentang kebaikan dari model regresi dalam memprediksi. Cara untuk mengetahuinya yaitu dengan membandingkan nilai $t$ hitung dengan nilai $t$ tabel. Apabila nilai $t$ hitung lebih besar dibandingkan dengan nilai $t$ tabel maka berarti t hitung tersebut signifikan artinya hipotesis alternatif diterima yaitu variabel independen secara individual mempengaruhi variabel dependen. Selain itu, bisa juga dilakukan dengan melihat $p$-value dari masing-masing variabel. Hipotesis diterima apabila $p$-value $<5 \%$ (Ghozali, 2006).

\section{HASIL DAN PEMBAHASAN}

\section{Hasil dan Pembahasan}

Untuk mendapatkan hasil regresi antar variabel independen dengan variabel dependen maka digunakan data sekunder yang bersumber dari Badan Pusat Statistik Provinsi Sulawesi Utara tahun 2006-2016. Data sekunder tersebut diestimasikan dengan metode OLS (Ordinary Least Suare) analisis regresi berganda sudah dijelaskan pada bab sebelumnya, dan diolah menggunakan program Eviews 8.1.

\section{1) Estimasi Model Penelitian}

\section{a. Kota Manado}

\section{Regresi Berganda}

Berikut hasil regresi untuk mengetahui Belanja Pemerintah, Investasi dan Luas Lahan terhadap Pertumbuhan Ekonomi di Kota Manado dengan menggunakan model OLS (Ordinary Least Suares). Hasil regresi bisa dilihat pada tabel 1 berikut:

\section{Tabel 1}

Estimasi Model BP, Inv, dan LH terhadap PE Kota Manado

\begin{tabular}{|l|c|c|c|}
\hline \multicolumn{1}{|c|}{ Variabel } & Coefficient & t-statistik & Probabilitas \\
\hline Belanja Pemerintah (BP) & -8.4700 & -0.482919 & 0.6544 \\
\hline Investasi (Inv) & -2.8300 & -0.028637 & 0.9785 \\
\hline Luas Lahan (LH) & -0.000105 & -0.237432 & 0.8240 \\
\hline $\mathrm{C}$ & 9.519379 & -0.482919 & 0.6544 \\
\hline $\mathrm{R}^{2}=0.074890$ & F-statistik $=0.107936$ \\
\hline
\end{tabular}




\section{Uji t-statistik}

Berdasarkan hasil estimasi pada tabel 1 berikut penjelasan hasil estimasi variabel Belanja Pemerintah, Investasi dan Luas Lahan terhadap Pertumbuhan Ekonomi di Kota Manado secara sendiri-sendiri atau parsial:

Hasil persamaan regresi belanja pemerintah (BP) mempunyai nilai koefisien -8.4700 yang berarti bahwa belanja pemerintah memiliki tanda negatif terhadap pertumbuhan ekonomi. Dengan demikian apabila belanja pemerintah naik maka pertumbuhan ekonomi akan turun hal ini tidak sesuai dengan teori. Dilihat dari nilai probabilitas sebesar 0.6544 lebih besar dari $\alpha$ $10 \%$ maka Ha ditolak dan Ho diterima. Varibel belanja pemerintah dengan nilai $\mathrm{t}$ hitung yakni 0.482919 dan $\mathrm{t}$ table 1.43976 dengan df 6 (n-k-1). Jadi, hitung $0.482919<\mathrm{t}$ tabel 1.43976 artinya tidak ada hubungan linier antara belanja pemerintah dengan pertumbuhan ekonomi.

Hasil persamaan regresi investasi (Inv) mempunyai nilai koefisien -2.8300 yang berarti bahwa investasi memiliki tanda negatif terhadap pertumbuhan ekonomi. Dengan demikian apabila investasi naik maka pertumbuhan ekonomi akan turun hal ini tidak sesuai dengan teori. Dilihat dari nilai probabilitas sebesar 0.9785 nilai ini lebih besar dari $\alpha 10 \%$. Maka Ha ditolak dan Ho diterima. Varibel investasi dengan nilai $\mathrm{t}_{\text {hitung }}$ yakni 0.028637 dan $\mathrm{t}_{\text {table }} 1.43976$ dengan df 6 (n-k-1). Jadi, hitung $0.028637<\mathrm{t}$ tabel 1.43976 artinya tidak ada hubungan linier antara investasi dengan pertumbuhan ekonomi.

Hasil persamaan regresi luas lahan (LH) mempunyai nilai koefisien -0.000105 yang berarti bahwa luas lahan memiliki tanda negatif terhadap pertumbuhan ekonomi. Dengan demikian apabila luas lahan naik maka pertumbuhan ekonomi akan turun hal ini tidak sesuai dengan teori. Dilihat dari nilai probabilitas sebesar 0.8240 nilai ini lebih besar dari $\alpha 10 \%$ maka

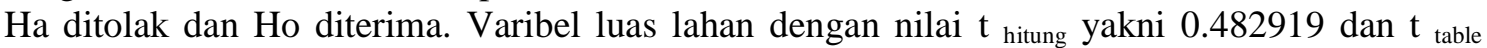
1.43976 dengan df $6(\mathrm{n}-\mathrm{k}-1)$. Jadi, hitung $0.482919<\mathrm{t}$ tabel 1.43976 artinya tidak ada hubungan linier antara luas lahan dengan pertumbuhan ekonomi.

\section{Uji f-statistik}

Berdasarkan hasil estimasi pada tabel 1 berikut penjelasan hasil estimasi variabel Belanja Pemerintah, Investasi dan Luas Lahan terhadap Pertumbuhan Ekonomi di Kota Manado secara bersama-sama atau simultan.

Nilai F-statistik yang diperoleh 0.107936 sedangkan F-tabel 3.07. Dengan demikian Fstatistik lebih kecil dari F-tabel yang artinya bahwa Belanja Pemerintah, Investasi dan Luas Lahan secara bersama-sama atau simultan tidak berpengaruh terhadap Pertumbuhan Ekonomi di Kota Manado.

\section{Uji Determinasi $\mathbf{R}^{2}$}

Nilai $\mathrm{R}^{2}$ yang diperoleh sebesar 0.074890. artinya, variasi perubahan Belanja Pemerintah, Investasi dan Luas Lahan terhadap Pertumbuhan Ekonomi sebesar 7.489\%, sedangkan sisanya (92.511\%) dijelaskan oleh variabel-variabel lain yang tidak dimasukan dalam model. 


\section{Asumsi Klasik}

Uji Asumsi klasik yang digunakan adal uji normalitas data, uji multikolinearitas dan uji heterokedastisitas. Variabel belanja pemerintah, investasi dan luas lahan terhadap pertumbuhan ekonomi di Kota Manado dinyatakan lolos uji asumsi klasik.

\section{b. Kota Bitung}

\section{Regresi Berganda}

Berikut hasil regresi untuk mengetahui Belanja Pemerintah, Investasi dan Luas Lahan terhadap Pertumbuhan Ekonomi di Kota Bitung dengan menggunakan model OLS (Ordinary Least Suares). Hasil regresi bisa dilihat pada tabel 2 berikut:

Tabel 2

Estimasi Model BP, Inv, dan LH terhadap PE Kota Bitung

\begin{tabular}{|l|c|c|c|}
\hline \multicolumn{1}{|c|}{ Variabel } & Coefficient & t-statistik & Probabilitas \\
\hline Belanja Pemerintah (BP) & 9.54000 & 2.941464 & 0.0423 \\
\hline Investasi (Inv) & -3.4800 & -0.404259 & 0.7067 \\
\hline Luas Lahan (LH) & 0.001947 & 2.336226 & 0.0797 \\
\hline $\mathrm{C}$ & -27.83922 & -2.029923 & 0.1122 \\
\hline $\mathrm{R}^{2}=0.731644$ & \multicolumn{3}{|c|}{ F-statistik $=3.635194$} \\
\hline
\end{tabular}

Eviews 8.1

\section{Uji t-statistik}

Berdasarkan hasil estimasi pada tabel 2 berikut penjelasan hasil estimasi variabel Belanja Pemerintah, Investasi dan Luas Lahan terhadap Pertumbuhan Ekonomi di Kota Bitung secara sendiri-sendiri atau parsial:

Hasil persamaan regresi belanja pemerintah (BP) mempunyai nilai koefisien 9.54000 yang berarti bahwa belanja pemerintah memiliki tanda positif terhadap pertumbuhan ekonomi. Dengan demikian apabila belanja pemerintah naik maka pertumbuhan ekonomi akan naik hal ini sesuai dengan teori. Dilihat dari nilai probabilitas sebesar 0.0423 lebih kecil dari $\alpha 10 \%$ maka Ha diterima dan Ho ditolak. Varibel belanja pemerintah dengan nilai $t$ hitung yakni 2.941464 dan $\mathrm{t}_{\text {table }} 1.43976$ dengan df 6 (n-k-1). Jadi, hitung $2.941464>\mathrm{t}_{\text {tabel }} 1.43976$ artinya ada hubungan linier antara belanja pemerintah dengan pertumbuhan ekonomi.

Hasil persamaan regresi investasi (Inv) mempunyai nilai koefisien -3.4800 yang berarti bahwa investasi memiliki tanda negatif terhadap pertumbuhan ekonomi. Dengan demikian apabila investasi naik maka pertumbuhan ekonomi akan turun hal ini tidak sesuai dengan teori. Dilihat dari nilai probabilitas sebesar 0.7067 nilai ini lebih besar dari $\alpha 10 \%$ maka Ha ditolak dan Ho diterima. Varibel investasi dengan nilai $\mathrm{t}_{\text {hitung }}$ yakni 0.404259 dan $\mathrm{t}_{\text {table }} 1.43976$ dengan df 6 (n-k-1). Jadi, hitung $0.404259<\mathrm{t}$ tabel 1.43976 artinya tidak ada hubungan linier antara investasi dengan pertumbuhan ekonomi. 
Hasil persamaan regresi luas lahan (LH) mempunyai nilai koefisien 0.001947 yang berarti bahwa luas lahan memiliki tanda positif terhadap pertumbuhan ekonomi. Dengan demikian apabila luas lahan naik maka pertumbuhan ekonomi akan naik hal ini sesuai dengan teori. Dilihat dari nilai probabilitas sebesar 0.0797 nilai ini lebih kecil dari $\alpha 10 \%$ maka Ha diterima dan Ho ditolak. Varibel luas lahan dengan nilai $t_{\text {hitung }}$ yakni 2.336226 dan $t_{\text {table }} 1.43976$ dengan df 6 (n-k-1). Jadi, hitung $2.336226>\mathrm{t}_{\text {tabel }} 1.43976$ artinya ada hubungan linier antara luas lahan dengan pertumbuhan ekonomi.

\section{Uji f-statistik}

Berdasarkan hasil estimasi pada table 2 berikut penjelasan hasil estimasi variabel Belanja Pemerintah, Investasi dan Luas Lahan terhadap Pertumbuhan Ekonomi di Kota Bitung secara bersama-sama atau simultan.

Nilai F-statistik yang diperoleh 3.635194 sedangkan F-tabel 3.07. Dengan demikian Fstatistik lebih besar dari F-tabel yang artinya bahwa Belanja Pemerintah, Investasi dan Luas Lahan secara bersama-sama atau simultan berpengaruh terhadap Pertumbuhan Ekonomi di Kota Bitung.

\section{Uji Determinasi $\mathbf{R}^{2}$}

Nilai $\mathrm{R}^{2}$ yang diperoleh sebesar 0.731644. Artinya, variasi perubahan Belanja Pemerintah, Investasi dan Luas Lahan terhadap Pertumbuhan Ekonomi sebesar $73.16 \%$, sedangkan sisanya $(26.84 \%)$ dijelaskan oleh variabel-variabel lain yang tidak dimasukan dalam model.

\section{Asumsi Klasik}

Uji Asumsi klasik yang digunakan adal uji normalitas data, uji multikolinearitas dan uji heterokedastisitas. Variabel belanja pemerintah, investasi dan luas lahan terhadap pertumbuhan ekonomi di Kota Bitung dinyatakan lolos uji asumsi klasik.

\section{c. Kota Kotamobagu}

\section{Regresi Berganda}

Berikut hasil regresi untuk mengetahui Belanja Pemerintah, Investasi dan Luas Lahan terhadap Pertumbuhan Ekonomi di Kota Kotamobagu dengan menggunakan model OLS (Ordinary Least Suares). Hasil regresi bisa dilihat pada tabel 3 berikut:

Tabel 3

Estimasi Model BP, Inv, dan LH terhadap PE Kota Kotamobagu

\begin{tabular}{|l|c|c|c|}
\hline \multicolumn{1}{|c|}{ Variabel } & Coefficient & t-statistik & Probabilitas \\
\hline Belanja Pemerintah (BP) & -1.2200 & -1.414121 & 0.2071 \\
\hline Investasi (Inv) & 2.8000 & 3.914028 & 0.0079 \\
\hline Luas Lahan (LH) & -3.3000 & -0.346004 & 0.7411 \\
\hline $\mathrm{C}$ & 7.431411 & 20.42653 & 0.0000 \\
\hline $\mathrm{R}^{2}=0.8121$ & \multicolumn{3}{|c}{ F-statistik = 8.6442 } \\
\hline \multicolumn{2}{|c|}{ Eviews 8.1 }
\end{tabular}




\section{Uji t-statistik}

Berdasarkan hasil estimasi pada tabel 3 berikut penjelasan hasil estimasi variabel Belanja Pemerintah, Investasi dan Luas Lahan terhadap Pertumbuhan Ekonomi di Kota Kotamobagu secara sendiri-sendiri atau parsial:

Hasil persamaan regresi belanja pemerintah (BP) mempunyai nilai koefisien -1.2200 yang berarti bahwa belanja pemerintah memiliki tanda negatif terhadap pertumbuhan ekonomi. Dengan demikian apabila belanja pemerintah naik maka pertumbuhan ekonomi akan turun hal ini tidak sesuai dengan teori. Dilihat dari nilai probabilitas sebesar 0.2071 lebih besar dari $\alpha$ 10\% maka Ha ditolak dan Ho diterima. Varibel belanja pemerintah dengan nilai $\mathrm{t}$ hitung yakni 1.4141 dan $\mathrm{t}_{\text {table }} 1.43976$ dengan df $6(\mathrm{n}-\mathrm{k}-1)$. Jadi, hitung $1.4141<\mathrm{t}_{\text {tabel }} 1.43976$ artinya tidak ada hubungan linier antara belanja pemerintah dengan pertumbuhan ekonomi.

Hasil persamaan regresi investasi (Inv) mempunyai nilai koefisien 2.8000 yang berarti bahwa investasi memiliki tanda positif terhadap pertumbuhan ekonomi. Dengan demikian apabila investasi naik maka pertumbuhan ekonomi akan naik hal ini sesuai dengan teori. Dilihat dari nilai probabilitas sebesar 0.0079 nilai ini lebih kecil dari $\alpha 10 \%$ maka Ha diterima dan Ho ditolak. Varibel investasi dengan nilai $\mathrm{t}_{\text {hitung }}$ yakni 3.9140 dan $\mathrm{t}_{\text {table }} 1.43976$ dengan df 6 (n-k-1). Jadi, hitung $3.9140>\mathrm{t}$ tabel 1.43976 artinya ada hubungan linier antara investasi dengan pertumbuhan ekonomi.

Hasil persamaan regresi luas lahan (LH) mempunyai nilai koefisien -3.3000 yang berarti bahwa luas lahan memiliki tanda negatif terhadap pertumbuhan ekonomi. Dengan demikian apabila luas lahan naik maka pertumbuhan ekonomi akan turun hal ini tidak sesuai dengan teori. Dilihat dari nilai probabilitas sebesar 0.7411 nilai ini lebih besar dari $\alpha 10 \%$ maka Ha ditolak dan Ho diterima. Varibel luas lahan dengan nilai $t$ hitung yakni 0.3460 dan $t$ table 1.43976 dengan df 6 (n-k-1). Jadi, hitung $0.3460<\mathrm{t}$ tabel 1.43976 artinya tidak ada hubungan linier antara luas lahan dengan pertumbuhan ekonomi.

\section{Uji f-statistik}

Berdasarkan hasil estimasi pada tabel 3 berikut penjelasan hasil estimasi variabel Belanja Pemerintah, Investasi dan Luas Lahan terhadap Pertumbuhan Ekonomi di Kota Kotamobagu secara bersama-sama atau simultan.

Nilai F-statistik yang diperoleh 8.6442 sedangkan F-tabel 3.07. Dengan demikian Fstatistik lebih besar dari F-tabel yang artinya bahwa Belanja Pemerintah, Investasi dan Luas Lahan secara bersama-sama atau simultan berpengaruh terhadap Pertumbuhan Ekonomi di Kota Kotamobagu.

\section{Uji Determinasi $\mathbf{R}^{2}$}

Nilai $\mathrm{R}^{2}$ yang diperoleh sebesar 0.8121. Artinya, variasi perubahan Belanja Pemerintah, Investasi dan Luas Lahan terhadap Pertumbuhan Ekonomi sebesar $81.21 \%$, sedangkan sisanya (18.79\%) dijelaskan oleh variabel-variabel lain yang tidak dimasukan dalam model.

\section{Asumsi Klasik}

Uji Asumsi klasik yang digunakan adal uji normalitas data, uji multikolinearitas dan uji heterokedastisitas. Variabel belanja pemerintah, investasi dan luas lahan terhadap pertumbuhan ekonomi di Kota Kotamobagu dinyatakan lolos uji asumsi klasik. 


\section{d. Kabupaten Minahasa}

\section{Regresi Berganda}

Berikut hasil regresi untuk mengetahui Belanja Pemerintah, Investasi dan Luas Lahan terhadap Pertumbuhan Ekonomi di Kabupaten Minahasa dengan menggunakan model OLS (Ordinary Least Suares). Hasil regresi bisa dilihat pada tabel 4 berikut:

\section{Tabel 4}

\section{Estimasi Model BP, Inv, dan LH terhadap PE Kabupaten Minahasa}

\begin{tabular}{|l|c|c|c|}
\hline \multicolumn{1}{|c|}{ Variabel } & Coefficient & t-statistik & Probabilitas \\
\hline Belanja Pemerintah (BP) & -7.0600 & -1.642473 & 0.1516 \\
\hline Investasi (Inv) & 5.7600 & 0.193933 & 0.8526 \\
\hline Luas Lahan (LH) & -2.3000 & -0.013856 & 0.9894 \\
\hline $\mathrm{C}$ & 6.008163 & 4.823825 & 0.0029 \\
\hline $\mathrm{R}^{2}=0.3904$ & \multicolumn{3}{|c|}{ F-statistik = 1.2812} \\
\hline \multicolumn{2}{|c|}{ Eviews 8.1 }
\end{tabular}

\section{Uji t-statistik}

Berdasarkan hasil estimasi pada tabel 4 berikut penjelasan hasil estimasi variabel Belanja Pemerintah, Investasi dan Luas Lahan terhadap Pertumbuhan Ekonomi di Kabupaten Minahasa secara sendiri-sendiri atau parsial:

Hasil persamaan regresi belanja pemerintah (BP) mempunyai nilai koefisien -7.0600 yang berarti bahwa belanja pemerintah memiliki tanda negatif terhadap pertumbuhan ekonomi. Dengan demikian apabila belanja pemerintah naik maka pertumbuhan ekonomi akan turun hal ini tidak sesuai dengan teori. Dilihat dari nilai probabilitas sebesar 0.1516 lebih besar dari $\alpha 5 \%$ maka Ha ditolak dan Ho diterima. Varibel belanja pemerintah dengan nilai $\mathrm{t}$ hitung yakni 1.642473 dan $\mathrm{t}_{\text {table }} 1.894$ dengan df 6 (n-k-1). Jadi, hitung $1.642473>\mathrm{t}_{\text {tabel }} 1.894$ artinya tidak ada hubungan linier antara belanja pemerintah dengan pertumbuhan ekonomi.

Hasil persamaan regresi investasi (Inv) mempunyai nilai koefisien 5.7600 yang berarti bahwa investasi memiliki tanda positif terhadap pertumbuhan ekonomi. Dengan demikian apabila investasi naik maka pertumbuhan ekonomi akan naik hal ini sesuai dengan teori. Dilihat dari nilai probabilitas sebesar 0.8526 nilai ini lebih besar dari $\alpha 10 \%$ maka Ha ditolak dan Ho diterima. Varibel investasi dengan nilai $\mathrm{t}_{\text {hitung }}$ yakni 3.9140 dan $\mathrm{t}_{\text {table }} 0.1939$ dengan df 6 (n-k-1). Jadi, hitung $0.1939<\mathrm{t}_{\text {tabel }} 1.43976$ artinya tidak ada hubungan linier antara investasi dengan pertumbuhan ekonomi.

Hasil persamaan regresi luas lahan (LH) mempunyai nilai koefisien -2.3000 yang berarti bahwa luas lahan memiliki tanda negatif terhadap pertumbuhan ekonomi. Dengan demikian apabila luas lahan naik maka pertumbuhan ekonomi akan turun hal ini tidak sesuai dengan teori. Dilihat dari nilai probabilitas sebesar 0.9894 nilai ini lebih besar dari $\alpha 10 \%$ maka Ha ditolak dan Ho diterima. Varibel luas lahan dengan nilai $\mathrm{t}$ hitung yakni 0.0138 dan $\mathrm{t}$ table 1.43976 dengan df 6 (n-k-1). Jadi, hitung $0.0138<\mathrm{t}_{\text {tabel }} 1.43976$ artinya tidak ada hubungan linier antara luas lahan dengan pertumbuhan ekonomi. 


\section{Uji f-statistik}

Berdasarkan hasil estimasi pada tabel 5.15 berikut penjelasan hasil estimasi variabel Belanja Pemerintah, Investasi dan Luas Lahan terhadap Pertumbuhan Ekonomi di Kabupaten Minahasa secara bersama-sama atau simultan.

Nilai F-statistik yang diperoleh 1.2812 sedangkan F-tabel 3.07. Dengan demikian Fstatistik lebih kecil dari F-tabel yang artinya bahwa Belanja Pemerintah, Investasi dan Luas Lahan secara bersama-sama atau simultan tidak berpengaruh terhadap Pertumbuhan Ekonomi di Kabupaten Minahasa.

\section{Uji Determinasi $\mathbf{R}^{2}$}

Nilai $\mathrm{R}^{2}$ yang diperoleh sebesar 0.3904. Artinya, variasi perubahan Belanja Pemerintah, Investasi dan Luas Lahan terhadap Pertumbuhan Ekonomi sebesar 39.04\%, sedangkan sisanya $(60.96 \%)$ dijelaskan oleh variabel-variabel lain yang tidak dimasukan dalam model.

\section{Asumsi Klasik}

Uji Asumsi klasik yang digunakan adal uji normalitas data, uji multikolinearitas dan uji heterokedastisitas. Variabel belanja pemerintah, investasi dan luas lahan terhadap pertumbuhan ekonomi di Kabupaten Minahasa dinyatakan lolos uji asumsi klasik.

\section{e. Kabupaten/Kepulauan Sangihe}

\section{Regresi Berganda}

Berikut hasil regresi untuk mengetahui Belanja Pemerintah, Investasi dan Luas Lahan terhadap Pertumbuhan Ekonomi di Kabupaten/Kepulauan Sangihe dengan menggunakan model OLS (Ordinary Least Suares). Hasil regresi bisa dilihat pada tabel 5 berikut:

\section{Tabel 5}

\section{Estimasi Model BP, Inv, dan LH terhadap PE Kabupaten Minahasa}

\begin{tabular}{|l|c|c|c|}
\hline \multicolumn{1}{|c|}{ Variabel } & Coefficient & t-statistik & Probabilitas \\
\hline Belanja Pemerintah (BP) & 9.1000 & 0.436946 & 0.6847 \\
\hline Investasi (Inv) & 1.3400 & 0.483630 & 0.6539 \\
\hline Luas Lahan (LH) & 0.000111 & 1.201316 & 0.2959 \\
\hline $\mathrm{C}$ & 1.572541 & 0.575694 & 0.5957 \\
\hline $\mathrm{R}^{2}=0.3883$ & \multicolumn{3}{|c}{ F-statistik = 0.8464 } \\
\hline \multicolumn{2}{|c|}{ Eviews 8.1 }
\end{tabular}

\section{Uji t-statistik}

Berdasarkan hasil estimasi pada tabel 5 berikut penjelasan hasil estimasi variabel Belanja Pemerintah, Investasi dan Luas Lahan terhadap Pertumbuhan Ekonomi di Kabupaten/kepulauan Sangihe secara sendiri-sendiri atau parsial:

Hasil persamaan regresi belanja pemerintah (BP) mempunyai nilai koefisien 9.1000 yang berarti bahwa belanja pemerintah memiliki tanda positif terhadap pertumbuhan ekonomi. Dengan demikian apabila belanja pemerintah naik maka pertumbuhan ekonomi akan naik hal ini 
sesuai dengan teori. Dilihat dari nilai probabilitas sebesar 0.6847 lebih besar dari $\alpha 10 \%$ maka Ha ditolak dan Ho diterima. Varibel belanja pemerintah dengan nilai $t_{\text {hitung }}$ yakni 0.436946 dan $t$ table 1.43976 dengan df 6 (n-k-1). Jadi, hitung $0.436946<\mathrm{t}$ tabel 1.43976 artinya tidak ada hubungan linier antara belanja pemerintah dengan pertumbuhan ekonomi.

Hasil persamaan regresi investasi (Inv) mempunyai nilai koefisien 1.3400 yang berarti bahwa investasi memiliki tanda positif terhadap pertumbuhan ekonomi. Dengan demikian apabila investasi naik maka pertumbuhan ekonomi akan naik hal ini sesuai dengan teori. Dilihat dari nilai probabilitas sebesar 0.6539 nilai ini lebih besar dari $\alpha 10 \%$ maka Ha ditolak dan Ho diterima. Varibel investasi dengan nilai $\mathrm{t}_{\text {hitung }}$ yakni 0.483630 dan $\mathrm{t}_{\text {table }} 0.1939$ dengan df 6 (n-k1). Jadi, hitung $0.483630<\mathrm{t}$ tabel 1.43976 artinya tidak ada hubungan linier antara investasi dengan pertumbuhan ekonomi.

Hasil persamaan regresi luas lahan (LH) mempunyai nilai koefisien 0.000111 yang berarti bahwa luas lahan memiliki tanda positif terhadap pertumbuhan ekonomi. Dengan demikian apabila luas lahan naik maka pertumbuhan ekonomi akan naik hal ini sesuai dengan teori. Dilihat dari nilai probabilitas sebesar 0.2959 nilai ini lebih besar dari $\alpha 10 \%$ maka $\mathrm{Ha}$ ditolak dan Ho diterima. Varibel luas lahan dengan nilai $t_{\text {hitung }}$ yakni 1.201316 dan $t_{\text {table }} 1.43976$ dengan df $6(\mathrm{n}-\mathrm{k}-1)$. Jadi, hitung $1.201316<\mathrm{t}$ tabel 1.43976 artinya tidak ada hubungan linier antara luas lahan dengan pertumbuhan ekonomi.

\section{Uji f-statistik}

Berdasarkan hasil estimasi pada tabel 5.18 berikut penjelasan hasil estimasi variabel Belanja Pemerintah, Investasi dan Luas Lahan terhadap Pertumbuhan Ekonomi di Kabupaten/Kepulauan sangihe secara bersama-sama atau simultan.

Nilai F-statistik yang diperoleh 0.8464 sedangkan F-tabel 3.07. Dengan demikian Fstatistik lebih kecil dari F-tabel yang artinya bahwa Belanja Pemerintah, Investasi dan Luas Lahan secara bersama-sama atau simultan tidak berpengaruh terhadap Pertumbuhan Ekonomi di Kabupaten/Kepulauan Sangihe.

\section{Uji Determinasi $\mathbf{R}^{2}$}

Nilai $\mathrm{R}^{2}$ yang diperoleh sebesar 0.3883. Artinya, variasi perubahan Belanja Pemerintah, Investasi dan Luas Lahan terhadap Pertumbuhan Ekonomi sebesar 38.83\%, sedangkan sisanya $(61,17 \%)$ dijelaskan oleh variabel-variabel lain yang tidak dimasukan dalam model.

\section{Asumsi Klasik}

Uji Asumsi klasik yang digunakan adal uji normalitas data, uji multikolinearitas dan uji heterokedastisitas. Variabel belanja pemerintah, investasi dan luas lahan terhadap pertumbuhan ekonomi di Kepulauan Sangihe dinyatakan lolos uji asumsi klasik.

\section{Pembahasan}

Setelah dilakukan estimasi dengan menggunakan analisis regresi berganda pada variabel Belanja Pemerintah (BP), Investasi (Inv) dan Luas Lahan (LH) terhadap Pertumbuhan Ekonomi (PE) di beberapa daerah di Provinsi Sulawesi Utara antara lain Kota Manado, Kota Bitung, Kota Kotamobagu, kabupaten Minahasa dan kepulauan sangihe selanjutnya akan dilihat variabel apa yang mempengaruhi Pertumbuhan Ekonomi di 6 daerah di Provinsi Sulawesi Utara. Perbandingannya dapat dilihat pada tabel 6 di bawah ini: 
Tabel 6

Perbandingan Nilai Regresi Persamaan BP, Inv dan LH terhadap PE di Kota Manado, Kota Bitung, Kota Kotamobagu, Kabupaten Minahasa dan kepulauan Sangihe

\begin{tabular}{|c|c|c|c|c|c|c|c|c|c|c|}
\hline \multirow{2}{*}{ Variabel } & \multicolumn{2}{|c|}{ Manado } & \multicolumn{2}{c|}{ Bitung } & \multicolumn{2}{c|}{ Kotamobagu } & \multicolumn{2}{c|}{ Minahasa } & \multicolumn{2}{c|}{ Sangihe } \\
\cline { 2 - 11 } & Coe & Prob & Coe & Prob & Coe & Prob & Coe & Prob & Coe & Prob \\
\hline BP & -8.4700 & 0.654 & $\mathbf{9 . 5 4 0 0 0}$ & $\mathbf{0 . 0 4 2}$ & -1.2200 & 0.207 & -7.0600 & 0.151 & 9.1000 & 0.684 \\
\hline Inv & -2.8300 & 0.978 & -3.4800 & 0.706 & $\mathbf{2 . 8 0 0}$ & $\mathbf{0 . 0 0 7}$ & 5.7600 & 0.852 & 1.3400 & 0.653 \\
\hline LH & -0.000105 & 0.824 & $\mathbf{0 . 0 0 1 9 4 7}$ & $\mathbf{0 . 0 7 9}$ & -3.300 & 0.741 & -2.300 & 0.989 & 0.000111 & 0.295 \\
\hline
\end{tabular}

Hasil Olah Data

Coe : Coeficient

Prob: Probability

Dilihat dari tabel perbandingan dengan menggunakan variabel Belanja Pemerintah, Investasi dan Luas Lahan ternyata hanya 2 dari 5 daerah penelitian yang mampu mendorong dan memberikan kontribusi bagi pertumbuhan ekonomi dimasing-masing daerah yakni Kota Bitung dan Kota Kotamobagu.

Dari hasil estimasi regresi berganda ternyata pertumbuhan ekonomi di Kota Bitung di pengaruhi oleh variabel belanja pemerintah dan luas lahan. Artinya, dengan adanya pertambahan belanja pemerintah akan memberikan pengaruh yang positif terhadap pertumbuhan ekonomi di Kota Bitung. Belanja pemerintah Kota Bitung sudah mampu mendorong pertumbuhan ekonomi yang ada di kota tersebut begitu juga dengan luas lahan sudah mampu memberikan kontribusi yang positif bagi pertumbuhan ekonomi Kota Bitung. Akan tetapi variabel investasi di Kota Bitung memberikan pengaruh yang negatif terhadap pertumbuhan ekonomi dan belum mampu mendorong pertumbuhan ekonomi secara signifikan.

Variabel investasi memberikan pengaruh yang positif bagi pertumbuhan ekonomi di Kota Kotamobagu. Ternyata Investasi yang ada di Kota Kotamobagu mampu mendorong dan memberikan kontribusi bagi pertumbuhan ekonomi di kota tersebut. Tetapi belanja pemerintah dan luas lahan di Kota Kotamobagu memberikan pengaruh yang negatif terhadap pertumbuhan ekonomi di daerah tesebut dan tidak memberikan dorongan pertumbuhan ekonomi yang

signifikan. Kepulauan Sangihe untuk variabel belanja pemerintah, investasi dan luas lahan memberikan pengaruh positif terhadap pertumbuhan ekonomi di daerah tersebut akan tetapi belum mampu mendorong dan memberikan kontribusi yang signifikan.

Variabel belanja pemerintah, investasi dan luas lahan memberikan pengaruh negatif terhadap pertumbuhan ekonomi di Kota Manado. Ternyata belanja pemerintah di Kota Manado tidak memberikan kontribusi bagi pertumbuhan ekonomi begitu juga dengan investasi yang dilakukan dan luas lahan yang bertambah di Kota Manado tidak memberikan dorongan pertumbuhan ekonomi secara signifikan.

\section{PENUTUP}

\section{Kesimpulan}

Dari hasil estimasi regresi berganda ternyata pertumbuhan ekonomi di Kota Bitung di pengaruhi oleh variabel belanja pemerintah dan luas lahan. Artinya, dengan adanya pertambahan belanja pemerintah akan memberikan pengaruh yang positif terhadap pertumbuhan ekonomi di Kota Bitung. Belanja pemerintah Kota Bitung sudah mampu mendorong 
pertumbuhan yang ada di kota tersebut begitu juga dengan luas lahan sudah mampu memberikan kontribusi yang positif bagi pertumbuhan ekonomi Kota Bitung. Akan tetapi variabel investasi di Kota Bitung memberikan pengaruh yang negatif terhadap pertumbuhan ekonomi dan belum mampu mendorong pertumbuhan ekonomi secara signifikan.

Variabel investasi memberikan pengaruh yang positif bagi pertumbuhan ekonomi di Kota Kotamobagu. Ternyata Investasi yang ada di Kota Kotamobagu mampu mendorong dan memberikan kontribusi bagi pertumbuhan ekonomi di kota tersebut. Tetapi belanja pemerintah dan luas lahan di Kota Kotamobagu memberikan pengaruh yang negatif terhadap pertumbuhan ekonomi di daerah tesebut dan tidak memberikan dorongan pertumbuhan ekonomi yang signifikan. Kepulauan Sangihe untuk variabel belanja pemerintah, investasi dan luas lahan memberikan pengaruh positif terhadap pertumbuhan ekonomi di daerah tersebut akan tetapi belum mampu mendorong dan memberikan kontribusi yang signifikan.

Variabel belanja pemerintah, investasi dan luas lahan memberikan pengaruh negatif terhadap pertumbuhan ekonomi di Kota Manado. Ternyata belanja pemerintah di Kota Manado tidak memberikan kontribusi bagi pertumbuhan ekonomi begitu juga dengan investasi yang dilakukan dan luas lahan yang bertambah di Kota Manado tidak memberikan dorongan pertumbuhan ekonomi secara signifikan.

\section{Saran}

Untuk mendapatkan pertumbuhan ekonomi secara berkenjutan, maka pihak pemerintah Provinsi, Kabupaten maupun Kota di Provinsi Sulawesi Utara perlu memberikan perhatian serius tentang bagaimana upaya-upaya yang harus dilakukan untuk meningkatkan pertumbuhan ekonomi. Terutama untuk faktor-faktor yang tidak memberikan kontribusi yang berarti bagi pertumbuhan ekonomi.

\section{DAFTAR PUSTAKA}

Acs, Zoltan J 2002. Innovation And The Growth Of Cities. Edward Elgar Publishing Limited : United Kingom

Ala, Andre Bayo, 1988. Kemiskinan dan strategi memerangi kemiskinan, Yogyakarta, Penerbit Liberty.

Arsyad Lincoln 1999, Pengantar Perencanaan dan Pembangunan Ekonomi Daerah, Edisi Pertama BPFE Yogyakarta.

Kaho, Josef Riwu. 1988. Prospek Otonomi di Negara Indonesia Jakarta. PT. Raja Grafindo Persada.

Kuncoro Mudrajad. 2000, Ekonomi Pembangunan, Teory Masalah dan Kebijakan, Penerbit UPP AMP YKPN, Yogyakarta.

Harvey John T, 2010 Neoliberalism, Neoclassismand Economic Welfare, Journal Of Economic Issues:44

Nugroho dan Rochmin Danuari , 2004. Pembangunan Wilayah, perspektif Ekonomi social dan lingkungan, pustaka LP3ES, Jakarta.

Tarigan, R,2006, perencanaan pembangunan wilayah, edisi revisi, Bumi Aksara, Jakarta panduan.

Todaro, Michael, $\mathbf{P}$ dan Stephen $\mathbf{C}$ Smith, 2006, Pembangunan Ekonomi, Edisi Kesembilan, Jakarta : Erlangga. 
Sadono Sukirno, 2006, mikro ekonomi, teory pengantar, edisi ketiga, Jakarta : raja grafindo persada.

Undang-undang nomor 17 tahun 2003 tentang pengelolaan Keuangan Negara.

Undang-undang No 33 tahun 2004 tentang keuangan daerah. 